\title{
Pendimethalin stresine maruz kalan aspir (Carthamus tinctorius L.)'de oluşan bazı biyokimyasal değişiklikler
}

\author{
Some biochemical changes in safflower (Carthamus tinctorius L.) plant exposed to \\ pendimethalin stress
}

\section{Gülçin Beker AKBULUT ${ }^{1}$ iD}

${ }^{1}$ Munzur Üniversitesi, Tunceli Meslek Yüksekokulu,Bitkisel ve Hayvansal Üretim Bölümü, Tunceli,Türkiye

\section{To cite this article:}

Akbulut, G.B. Pendimethalin

(2019). stresine maruz kalan aspir (Carthamus tinctorius L.)'de oluşan bazı biyokimyasal değişiklikler. Harran Tarım ve Gıda Bilimleri Dergisi, 23(1): 90-98.

DOI: 10.29050/harranziraat.37852 2

\footnotetext{
Address for Correspondence: Gülçin Beker AKBULUT e-mail:

gulcinakbulut@munzur.edu.tr
}

Received Date:

13.01.2018

Accepted Date:

30.11 .2018

\section{Öz}

Pendimethalin herbisiti tarımsal uygulamalarda yabancı otların kontrolü için yaygın olarak kullanılmaktadır. Bununla birlikte, pendimethalinin kültür bitkileri üzerindeki yan etkisi tam olarak bilinmemektedir. Bu çalışmada, aspir (Carthamus tinctorius L.) bitkisine ait Dinçer ve Remzibey çeşitlerinde pendimethalin kaynaklı oksidatif stres araştırıldı. Herbisit uygun büyüklüğe (21 günlük) gelen bitkilerin yapraklarına toksisite denemeleri sonrasında belirlenen dozlarda (0.004-0.01 M) çimlenme sonrası olarak uygulandı. Uygulama gruplarında karotenoid, toplam klorofil, toplam karbohidrat, toplam fenolik ve lipid peroksidasyonunu gösteren malondialdehid (MDA) içeriğindeki değişimler saptandı. Dinçer (\% 42.7) ve Remzibey (\% 59) çeşitlerinde karotenoid içeriği kontrole kıyasla azalış gösterdi. Toplam klorofil içeriği Remzibey çeşidinde (\% 56.8) Dinçer'e (\% 41.4) göre daha yüksek bulundu. Toplam karbohidrat içeriği Dinçer çeşidinde (\% 50) Remzibey çeşidine (\% 46.1) kıyasla daha yüksek saptandı. Toplam fenolik içeriği Remzibey (\% 48.3) ve Dinçer (\% 46.7) çeşitlerinde artan saatlere bağlı olarak azalış gösterdi. MDA içeriği Remzibey çeşidinde (\% 72) Dinçer çeşidine (\% 70) göre daha yüksek saptandı. Bu çalışma, pendimethalinin kültür bitkisi olan aspire toksik etki oluşturduğunu göstermiştir.

Anahtar Kelimeler: Aspir, Carthamus tinctorius, Pendimethalin, Malondialdehid, Karotenoid

\section{ABSTRACT}

Pendimethalin herbicide is widely used for controlling weeds in agricultural applications. However, the side effect of pendimethalin on cultivated plants is unknown. In this study, oxidative stress induced by pendimethalin in safflower plant (Carthamus tinctorius L.) was investigated. In this study, oxidative stress induced by pendimethalin in Dinçer and Remzibey cultivars of safflower was investigated. The herbicide was applied after germination at the doses determined (0.004-0.01 M) following toxicity tests to the leaves of plants of suitable size (21 days). In application groups, carotenoids, total chlorophyll, total carbohydrate, total phenolic and malondialdehyde (MDA) content indicating lipid peroxidation were investigated. The content of carotenoid in Dinçer (42.7\%) and Remzibey (59 \%) cultivars decreased compared to control. Total chlorophyll content was significantly higher in Remzibey cultivar $(56.8 \%)$ than Dinçer cultivar (41.4 $\%)$. In Dinçer cultivar (50\%), carbohydrate content was found to be higher than Remzibey cultivar (46.1\%). Total phenolic content decreased with increasing hours in Remzibey (48.3\%) and Dinçer (46.7\%) cultivars. MDA content was higher in Remzibey cultivar (72.4\%) than Dinçer cultivar (70.1\%). This study has shown that pendimethalin herbicide has a toxic effect on safflower, which is a cultural plant.

Key Words: Safflower, Carthamus tinctorius, Pendimethalin, Malondialdehyde, Carotenoid 


\section{Giriş}

Çevre şartlarının bir bitkinin normal büyüme ve gelişmesini olumsuz yönde etkileyecek kadar değişmesi durumu stres olarak tanımlanır. Bitkiler yaşamları sürecinde birçok stres faktörü ile karşılaşmaktadırlar. Stres faktörleri biyotik ve abiyotik olmak üzere ikiye ayrılmaktadır (Levitt, 1972).

Reaktif oksijen türleri (ROT) bitkilerde endojen olarak kloroplastlardaki fotosentez reaksiyonlarında, plastit ve peroksizomlarda, mitokondrilerdeki sitrik asit döngüsünde $\mathrm{NADPH}$ oksidaz, hücre duvarı peroksidazları ve amino oksidazlar gibi enzimlerin etkisiyle oluşan serbest radikallerdir (Van Camp ve ark., 1998; Van Breusegem ve Dat, 2006). Çevresel strese karşı ROT'leri ikincil haberciler olarak da rol oynamaktadırlar. Hücresel ROT konsantrasyonunun artması ile antioksidan savunma sistemleri ve ROT üretimi arasındaki denge bozularak bitkiler oksidatif strese girmektedir. ROT üretiminin artışı lipitlerin peroksidasyonuna, proteinlerin oksidasyonuna, nükleik asit hasarına, enzim inhibisyonuna ve hücrelerin ölümüne kadar birçok hasara neden olmaktadır (Smirnoff, 1993; Breusegem ve Dat, 2006; Büyük ve ark., 2012).

Dünya nüfusunun hızla artışına paralel olarak kullanılabilir tarım alanlarının gün geçtikçe azalması bu sorunun önemini her geçen gün daha da artırmaktadır. Sorunun çözümü için yapılan ıslah ve gübreleme gibi çalışmaların yanı sıra temel besin kaynaklarındaki verim kaybını engellemek amacıyla çeşitli zararlılara karşı açılan savaş da önemli bir yer tutmaktadır. Verim kaybına neden olan zararlılar için yürütülen fiziksel ve biyolojik savaş uzun, zahmetli ve masraflı olduğu için daha çabuk ve etkin bir yöntem olarak kimyasal savaş uygulanmaktadır (Kışlalıoğlu ve Berkes, 1985; Erdoğan, 2010). Pestisitler, zararlılar tarafından oluşturulan hasarı önleyen, kontrol eden ya da azaltmak için kullanılan doğal ya da sentetik organik bileşiklerdir. Pestisit; kimyasal bir madde, biyolojik ajan, antimikrobiyal ya da dezenfektan olabilir
(Squibb, 2002). Yoğun ve bilinçsiz pestisit kullanımının sonucunda gıdalarda, toprak, su ve havada kullanılan pestisitin kendisi ya da dönüşüm ürünleri kalabilmektedir. Tarımsal ürün zararlılarında meydana gelen çeşitli tipteki dayanıklılıklar sonucunda pestisitin etkinliğindeki azalmayı aşmak için daha yüksek dozlarda uygulama gerekmektedir. Bu da hem maliyetin artmasına ve ürün veriminde azalmalara yol açmakta, hem de üründe ve çevrede kalıntı miktarının ve kirliliğin artmasına neden olmaktadır (Delen ve ark., 2005).

Yabancı ot istenmeyen bitki olarak tanımlanır ve yabancı otların kontrolü optimum ürün yetişmesi için çok önemlidir. Yabancı otlar ürünle ışık, nem ve besin maddeleri için yarışır. Tarımsal mücadele amaçlı kullanılan kimyasallar içerisinde herbisitler önemli bir yer almaktadır. Herbisitler yabancı otların gelişimini kontrol etmek için kullanılan maddelerdir (Heap, 2014; Ghanizadeh ve ark., 2015). Herbisitler bitkilerin çimlenen tohumlarıyla, kökleriyle, sürgünleriyle ya da yapraklarıla temas kurabilirler. Herbisitler çoğunlukla hedef olarak kullanıldıkları bitkiyle beraber bu bitki üzerinde yaşayan ve beslenen tüm canlıları olumsuz yönde etkilemektedir. Farklı grup herbisitlerle ilgili olarak, bitkilerde fotosentez, amino asit, lipit sentezi, hücre zarı, pigmentler, hormonlar ve kök gelişimi gibi kriterler üzerinde pek çok araştırma yapılmıştır (Mengistu ve ark., 2000; Zhou ve ark., 2007; Macedo ve ark., 2008).

Pendimethalin çıkış sonrası uygulamalarda yaygın olarak kullanılan bir herbisit türüdür. Bu herbisit, aspir bitkileri arasında bulunan yabancı otların yapraklarına uygulanmakta, dolayısı ile ortamda bulunan aspir bitkileri de bu uygulamadan direkt olarak etkilenmektedir (Jha ve ark., 2017).

Aspir özellikle tohumları yemeklik yağ ve kuşyemi olarak kullanılan Asteraceae familyasının bir üyesidir (Dajue ve Mündel, 1996). Sınırlı alanlarda ekilmesine ve üretiminin az olmasına rağmen, tarım sistemleri içerisinde önemli bir role sahiptir. Aspir; soya, kolza, ayçiçeği gibi diğer yağı tohumlu bitkilere oranla çok daha az suya ihtiyaç 
duyan, kurak koşullarda da yetişebilen ve son dönemlerde önemi artan yağı tohum bitkisidir. Aspir tarımında karşılaşılan en önemli problemlerden birisi yabancı otlarla mücadeledir (Gilbert, 2008).

$\mathrm{Bu}$ araştırmada ülkemizde son yıllarda tarımı gittikçe yaygınlaşan yüksek besinsel içeriği ile gıda ve yem sanayi açısından ekonomik değere sahip önemli bir endüstriyel tarımsal ürün olan aspir (Carthamus tinctorius L.) bitkisinde, tarımsal verimini arttırmak amacı ile zararlı otlara karşı kullanılan pendimethalin herbisitin bitkinin biyokimyasal yapısında ortaya çıkaracağı değişiklikleri analiz etmek, bitki verimi, insan ve hayvan sağığı açısından varsa muhtemel risklerini ortaya koymaktır.

\section{Materyal ve Metot}

Araştırmada kullanılacak olan pendimethalin (Stomp) herbisiti BASF firmasından, Dinçer ve Remzibey çeşitlerine ait aspir tohumları Geçit Kuşağı Tarımsal Araştırma Enstitüsü'nden temin edildi. Yapılan ön denemelerde, aspir tohumları farklı konsantrasyonlarda herbisite maruz bırakılıp çimlenme yüzdelerine paralel olarak toksisite dozları (0.004 M, 0.005 M, $0.007 \mathrm{M}$ ve $0.01 \mathrm{M}$ ) belirlendi. Bundan sonraki aşamada gerçekleştirilen deneylerde; saksıda perlit içerisinde yürütüldü. Besin çözeltisi Hoagland ve Arnon (1938)'a göre hazırlandı. Bu uygulamaya paralel olarak çimlenmeyi takiben çimlenme sonrası gruplarda üçüncü haftada herbisit uygulaması yapıldı. Uygulama yapılan yapraklardan 24 . 48 . ve 72 . saatlerde alınarak karotenoid, toplam klorofil, toplam şeker, toplam fenolik ve lipid peroksidasyonu analizleri yapıldı.

Karotenoid ve toplam klorofil içeriklerinin belirlenmesi

Pigmetlerin ekstraksiyonu işlemlerinde De Kok ve Graham (1980) yöntemi kullanıldı. Ekstraksiyon işlemleri için parçalayıcıda öğütülen taze yaprak örneklerinden her bir örnek için üç tekrarlı olmak üzere birer gram alınıp cam havanda $50 \mathrm{~mL}$ aseton içerisine konularak homojenize edildikten sonra santrifüj edildi. Santrifüj edilen örneklerin absorbans değerleri Lichtenthaler ve Welburn (1983)'a göre spektrofotometrede (Shimadzu UV1201V) 470, 645 ve $662 \mathrm{~nm}$ 'de okunarak karotenoid ve toplam klorofil miktarları hesaplandı.

\section{Toplam şeker analizi}

Toplam şeker miktarı Rosenberg (1980)'e göre yapıldı. Yaprak örnekleri küçük parçalara ayrılıp, bir gün süreyle $50{ }^{\circ} \mathrm{C}^{\prime}$ de bekletildi. Daha sonra parçalayıcıda öğütülerek tekrar bir gece $50{ }^{\circ} \mathrm{C}^{\prime} \mathrm{de}$ bekletildi. Örnekler 24 saat sonra desikatöre alınarak bir saat bekletilerek örneklerden $0.2 \mathrm{gr}$ tartılıp üzerine, $5 \mathrm{~mL} \% 72(\mathrm{w} / \mathrm{w})^{\prime}$ 'lik $\mathrm{H}_{2} \mathrm{SO}_{4}$ ilave edildi ve 15 dakikada bir karıştırılarak üç saat hidroliz edildi. Daha sonra $45 \mathrm{~mL}$ distile su ilave edilerek bir gece buzdolabında bekletildi. Örnekler 24 saat sonra filtre kağıtlarından süzüldü. Süzüntü $10^{-2}$ oranında seyreltildikten sonra $500 \mu L^{\prime}$ sine günlük olarak hazırlanmış antron reaktifinden $2 \mathrm{~mL}$ eklenerek vortekste hızla karıştırıldı. Bu karışım tüplere konularak ağızları alüminyum folyo ile kapatıldı. Tüpler kaynar su banyosunda $10 \mathrm{dk}$ tutuldu ve daha sonra $620 \mathrm{~nm}$ dalga boyunda spektrofotometrede, distile su ile aynı işlemler yapılarak kontrole karşı okundu. Glukoz değerleri bilgisayarda Slide programında girilen standart değerlere karşılık hesaplandı.

\section{Toplam fenolik analizi}

Toplam fenolik içeriği, Slinkard ve Singleton (1977) ile Chandler ve Dodds (1983)'a göre yapıldı. $0.05 \mathrm{gr}$ yaprak dokusu üzerine $2.5 \mathrm{~mL}$ etanol eklenerek homojenize edildi ve $80^{\circ} \mathrm{C}^{\prime}$ de 24 saat bekletildi. Örnekler ertesi gün çalkalamalı etüvde bir gün boyunca bekletildikten sonra santrifüj edilerek $1 \mathrm{~mL}$ süpernatan üzerine $1 \mathrm{~mL}$ etanol, $5 \mathrm{~mL}$ distile su ve $1 \mathrm{~mL}$ folin eklenerek $3 \mathrm{dk}$ çalkalamalı etüvde bırakıldı. Karışım üzerine $3 \mathrm{~mL}$ $\% 2(\mathrm{w} / \mathrm{v})^{\prime}$ lik $\mathrm{Na}_{2} \mathrm{CO}_{3}$ eklenerek 2 saat karanlıkta bırakılıp daha sonra $760 \mathrm{~nm}$ 'de okuma yapıldı. Aynı yöntem gallik asit solüsyonuyla tekrar edilerek standart eğri hazırlandı.

\section{Lipid peroksidasyonu analizi}

Yöntem Heath ve Packer (1968)'a göre yapıldı, $0,5 \mathrm{gr}$ taze yaprak dokusu $5 \mathrm{~mL} \% 0,1^{\prime}$ lik TCA içinde homojenize edildi. Homojenat $10,000 \mathrm{~g}$ 'de 10 dakika santrifüj edildi. Bu solüsyonun $2 \mathrm{~mL}$ 'si 2 $\mathrm{mL} \%$ 0,5'lik TBA (\% 20'lik TCA içinde hazırlanan) ile 30 dakika $95^{\circ} \mathrm{C}$ 'de su banyosunda bekletildi ve süre bitiminde örnekler buza alındı. Daha sonra 10,000 g'de 15 dakika santrifüj edildi. Süpernatanın absorbansı $532 \mathrm{~nm}$ ve $600 \mathrm{~nm}$ 'de ölçülerek, 600 nm'de yapılan ölçümler 532 nm'de 
yapılan ölçümlerden çıkarılarak doğrulandı. MDA miktarı $155 \mathrm{mM}^{-1} \mathrm{~cm}^{-1}$ ekstinksiyon katsayısıyla hesaplandı.

\section{Istatistiksel analizler}

Elde edilen veriler tesadüf blokları deneme desenine göre SPSS 17.0 paket programında istatistiki analize tabi tutuldu, ortalamalar arasındaki farklılıklar Duncan (1955) ve bağımsız " $t$ " testleri kullanılarak saptandı. Analizlerde $p<0.05$ istatistiksel olarak önemli kabul edilmiştir.

\section{Araştırma Bulguları ve Tartışma}

\section{Karotenoid içerikleri}

Pendimethalin uygulanan Dinçer çeşidinde en yüksek karotenoid miktarları kontrol gruplarında 24., 48. ve 72. saatlerde belirlendi. Pendimethalin herbisiti uygulanan gruplarda artan saatlere bağlı olarak (0.04 M hariç) karotenoid miktarı da artış gösterdi. En düşük karotenoid miktarı 24. saatte $0.01 \mathrm{M}$ pendimethalin uygulanan gruplarda 1.33 $\mu \mathrm{g} \mathrm{g}^{-1}, 48$. saatte $0.005 \mathrm{M}$ pendimethalin uygulanan gruplarda $1.63 \mu \mathrm{g} \mathrm{g}^{-1}$ ve 72 . saatte $0.007 \mathrm{M}$ pendimethalin uygulanan gruplarda 1.87 $\mu \mathrm{g} \mathrm{g}^{-1}$ olarak saptandı. Konsantrasyon artışı ve saatlere bağlı olarak gözlenen bu değişimler istatistiksel olarak anlamlı bulundu (Şekil 1).

Pendimethalin uygulanan Remzibey çeşitinde en yüksek karotenoid miktarları kontrol gruplarında 24., 48. ve 72. saatlerde belirlendi. En düşük karotenoid miktarı 24. saatte $0.01 \mathrm{M}$ pendimethalin uygulanan gruplarda $1.61 \mathrm{\mu g} \mathrm{g}^{-1}$, 48. saatte $0.01 \mathrm{M}$ pendimethalin uygulanan gruplarda $1.41 \mu \mathrm{g} \mathrm{g}^{-1}$ ve 72 . saatte $0.007 \mathrm{M}$ pendimethalin uygulanan gruplarda $1.29 \mu \mathrm{g} \mathrm{g}^{-1}$ olarak belirlendi. Konsantrasyon artışı ve saatlere bağlı olarak gözlenen bu değişimler istatistiksel olarak anlamlı bulundu (Şekil 1).

Karotenoidler bitkilerde oksidatif hasara karşı koruyucu rol oynamaktadırlar (Li ve ark. 2010). Marchezan ve ark. tarafından (2017) yapılan bir çalışmada çeltik bitkisine uygulanan imazethapyr + imazapic ve imazapyr+imazapic herbisitleri sonrasında karotenoid ve total klorofil içeriklerinin büyük azalış gösterdiği belirtilmiştir.

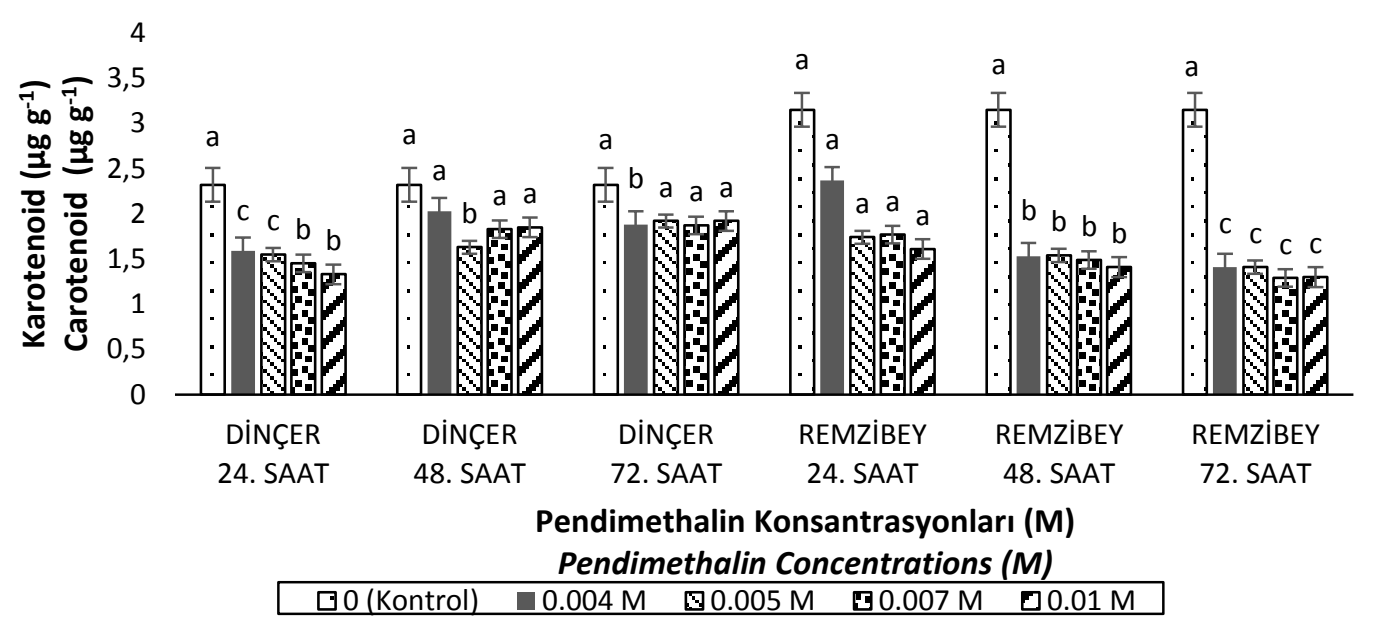

Şekil 1. Pendimethalin herbisitinin Dinçer ve Remzibey çeşitlerinde karotenoid içerikleri üzerine etkileri. Farklı küçük harfler pendimethalinin farklı konsantrasyonlarına bağı olarak saatler arasındaki önemli farklılıkları Duncan testine göre $(p<0.05)$ göstermektedir

Figure 1. Effects of pendimethalin herbicide on carotenoid contents in Dinçer and Remzibey varieties. Different small letters experience changes due to different concentrations of pendimethalin according to Duncan test $(p<0.05)$

\section{Toplam klorofil içerikleri}

Pendimethalin uygulanan Dinçer çeşitinde en yüksek toplam klorofil miktarları kontrol gruplarında 24., 48. ve 72. saatlerde saptandı. Toplam klorofil içeriği 24. saatte en düşük 0.005 $\mathrm{M}$ uygulanan gruplarda $6.34 \mu \mathrm{g} \mathrm{g} \mathrm{g}^{-1}, 48$. saatte 0.01 $\mathrm{M}$ uygulanan gruplarda $6.22 \mu \mathrm{g} \mathrm{g}^{-1}$ ve 72 . saatte $0.01 \mathrm{M}$ uygulanan gruplarda $5.79 \mu \mathrm{g} \mathrm{g}^{-1}$ olarak belirlendi. Konsantrasyon artışı ve saatlere bağı olarak gözlenen bu değişimler istatistiksel olarak anlamlı bulundu (Şekil 2).

Pendimethalin uygulanan Remzibey çeşitinde en yüksek toplam klorofil miktarları kontrol gruplarında 24., 48. ve 72. saatlerde belirlendi. En düşük toplam klorofil içeriği 24. saatte $0.007 \mathrm{M}$ uygulanan gruplarda $6.32 \mu \mathrm{g} \mathrm{g}^{-1}, 48$. saatte 0.004 
$\mathrm{M}$ uygulanan gruplarda $6.16 \mu \mathrm{g} \mathrm{g}^{-1}$ ve 72 . saatte $0.01 \mathrm{M}$ uygulanan gruplarda $5.93 \mathrm{\mu gg}^{-1}$ olarak belirlendi. Konsantrasyon artışı ve saatlere bağlı olarak gözlenen bu değişimler istatistiksel olarak anlamlı bulundu (Şekil 2). Toplam klorofil içeriğindeki azalış klorofil yıkımından sorumlu olan klorofillaz enziminin artışından kaynaklanabilir.

Klorofil içeriği çoğu zaman çevresel streslerin etkisini değerlendirmek için kullanılmaktadır. Boukehili ve ark. (2014) tarafından yapılan bir çalışmada \% 4.1. Triasulfuron ve \%65.9 Dicamba içeren Zoom ve \% 75 metrubizin içeren Sencorate herbisitlerine maruz kalan Orthotrichum affine (3, 7 ve 14 gün) bitkisinde klorofillerin önemli farklılıklar gösterdiği belirtilmiştir ( $a, b$ ve $a+b)$. Langaro ve ark. tarafından (2017) yapılan bir çalışmada pirinç bitkisine uygulanan oxyfluorfen ve pendimethalin herbisitinin pigment içeriğini değiştirdiği belirtilmiştir.

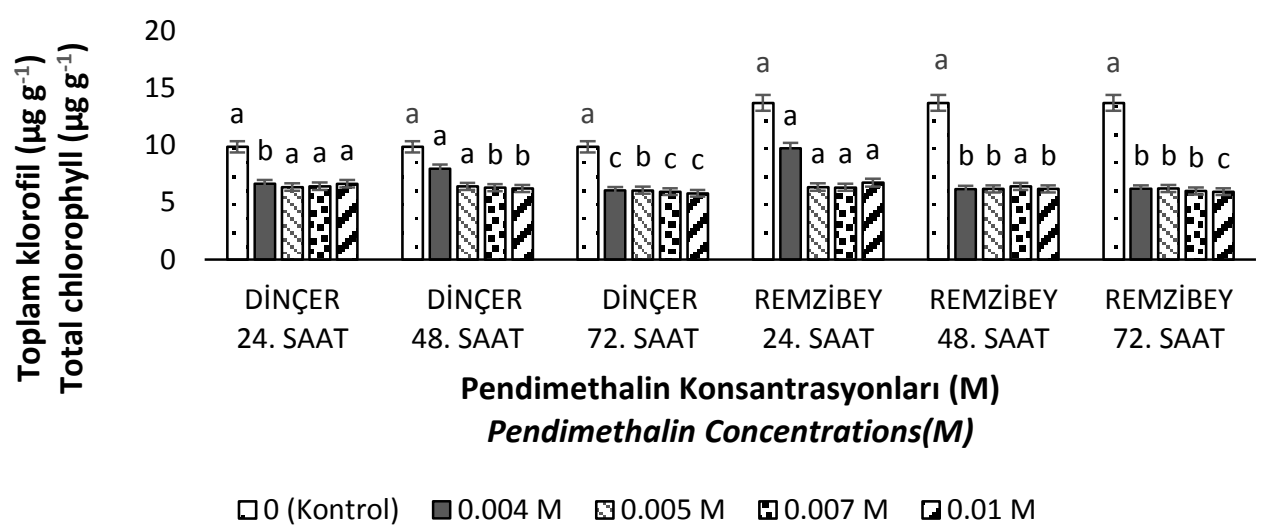

Şekil 2. Pendimethalin herbisitinin Dinçer ve Remzibey çeşitlerinde toplam klorofil içerikleri üzerine etkileri. Farklı küçük harfler pendimethalinin farklı konsantrasyonlarına bağlı olarak saatler arasındaki önemli farklılıkları Duncan testine göre $(p<0.05)$ göstermektedir.

Figure 2. Effects of pendimethalin herbicide on total chlorophyll contents in Dinçer and Remzibey varieties. Different small letters experience changes due to different concentrations of pendimethalin according to Duncan test $(p<0.05)$.

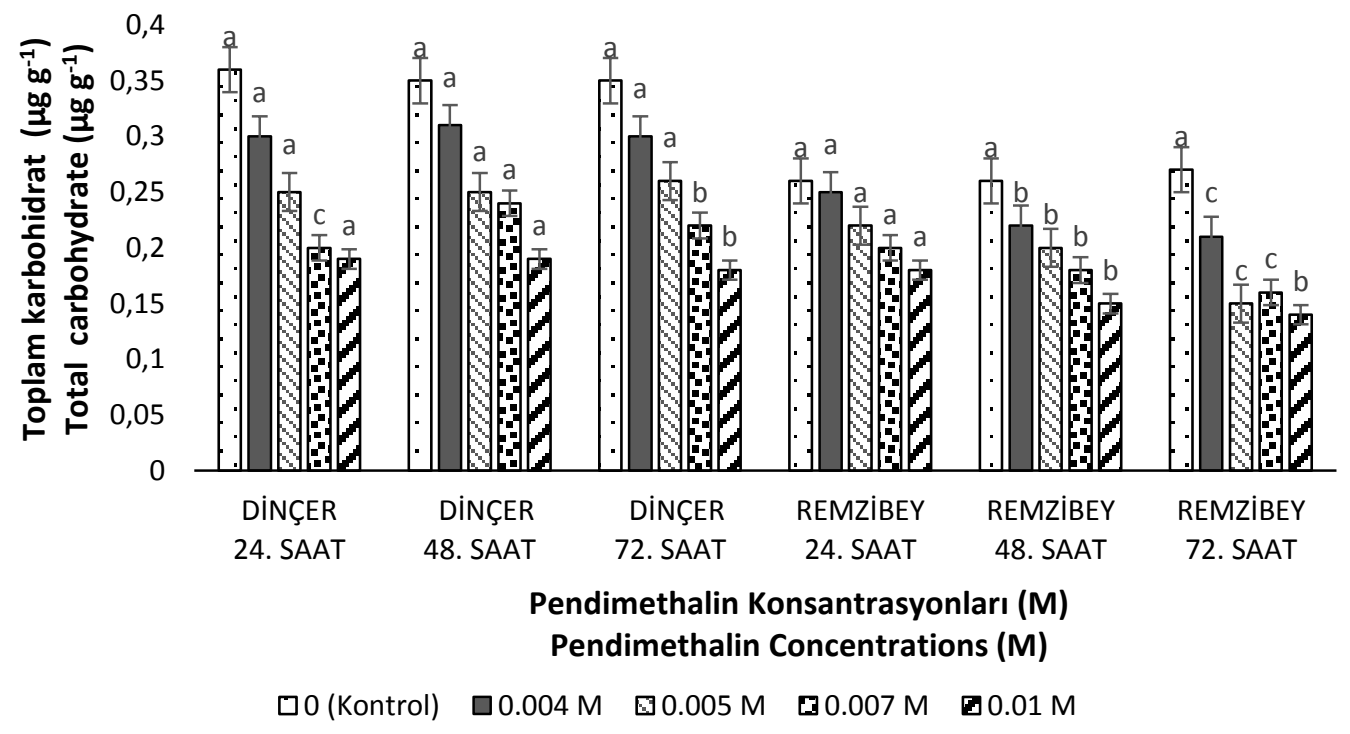

Şekil 3. Pendimethalin herbisitinin Dinçer ve Remzibey çeşitlerinde toplam karbohidrat içerikleri üzerine etkileri. Farklı küçük harfler pendimethalinin farklı konsantrasyonlarına bağlı olarak saatler arasındaki önemli farklılıkları Duncan testine göre $(p<0.05)$ göstermektedir.

Figure 3. Effects of pendimethalin herbicide on total carbohydrate contents in Dinçer and Remzibey varieties. Different small letters experience changes due to different concentrations of pendimethalin according to Duncan test ( $p<0.05)$. 
Dinçer ve Remzibey çeşitlerinde toplam karbohidrat miktarları incelendiğinde en yüksek toplam karbohidrat miktarı 24., 48. ve 72. saatlerde kontrol gruplarında belirlendi. En düşük karbohidrat miktarı Dinçer ve Remzibey çeşitlerinde 72. saatte $0.01 \mathrm{M}$ pendimethalin uygulanan gruplarda sırasıyla $0.18 \mu \mathrm{g} \mathrm{g}^{-1}$ ve 0.14 $\mu \mathrm{g} \mathrm{g}^{-1}$ saptandı. Konsantrasyon artışı ve saatlere bağı olarak gözlenen değişimler istatistiksel olarak anlamlı bulundu (Şekil 3). Saladin ve ark., (2003) tarafından yapılan bir çalışmada flumioxazin herbisitinin Vitis vinifera'ya uygulaması sonrasında uygulamayı takiben karbohidrat içeriğinin ilk haftada azaldığı belirtilmektedir.

\section{Toplam fenolik içerikleri}

Dinçer çeşitinde en yüksek toplam fenolik miktarları 24. ve 48 . saatlerde $0.01 \mathrm{M}$ pendimethalin uygulanan gruplarda $3.02 \mathrm{\mu g} \mathrm{g}^{-1}$ ve $2.39 \mu \mathrm{g} \mathrm{g}^{-1}, 72$ saatte $0.007 \mathrm{M}$ pendimethalin uygulanan gruplarda $1.75 \mu \mathrm{g} \mathrm{g}^{-1}$ olarak saptandı. Konsantrasyon artışı ve saatlere bağlı olarak gözlenen değişimler istatistiksel olarak anlamlı bulundu (Şekil 4). Remzibey çeşidinde en yüksek toplam fenolik miktarları 24. ve 48. saatlerde 0.01 $\mathrm{M}$ pendimethalin uygulanan gruplarda $2.96 \mu \mathrm{g} \mathrm{g}^{-1}$ ve $2.45 \mu \mathrm{g} \mathrm{g}^{-1}, 72$.saatte $0.007 \mathrm{M}$ pendimethalin uygulanan gruplarda $1.58 \mu \mathrm{g} \mathrm{g}^{-1}$ olarak saptandı. Konsantrasyon artışı ve saatlere bağlı olarak gözlenen değişimler istatistiksel olarak anlamlı bulundu (Şekil 4).

Fenolik bileşikler antioksidan özelliklere sahiptir ve artışlarıyla hücresel bileşikler korunabilir (Romani ve ark., 2003). Dragicevic ve ark. (2010) tarafından yapılan bir çalışmada farklı herbisitlerin kullanılması fenolik bileşiklerin içeriğini farklı mısır genotiplerinde artırdığı ya da azalttığı belirtilmiştir. Malenčić ve ark., (2008) tarafından yapılan bir çalışmada Soya fasulyesine ve ilgili yabancı otlara Ambrosia artemisiifolia L., Chenopodium album L., Convolvulus arvensis L and Sinapis arvensis L. linuron ve dimethenamid herbisitlerini uygulamışlardır. Uygulama sonrasında total fenolik içeriğinde soya fasulyesinde kontrole kıyasla $\% 43, A$. artemisiifolia'da \% 21.1 ve S. arvensis'de \% 6 artış bulunduğu belirtilmiştir.

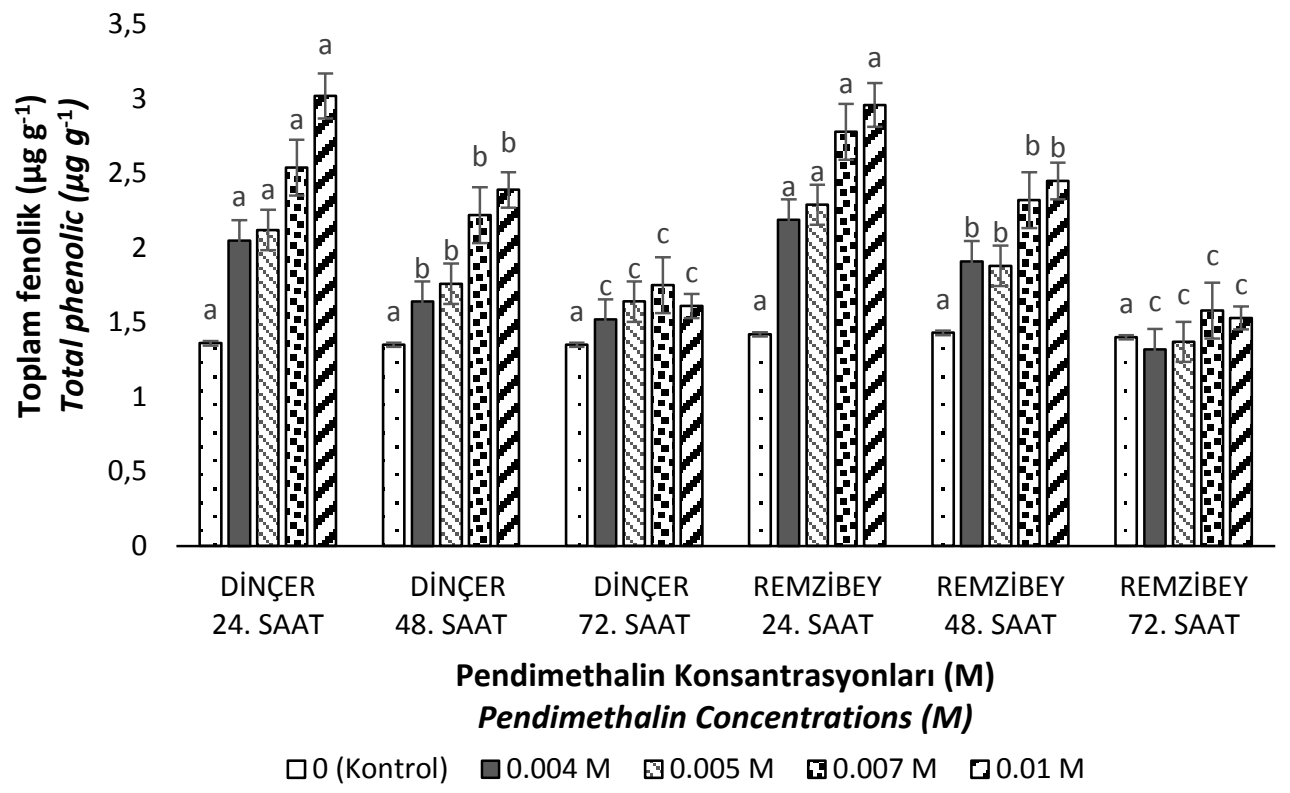

Şekil 4. Pendimethalin herbisitinin Dinçer ve Remzibey çeşitlerinde toplam fenolik içerikleri üzerine etkileri. Farklı küçük harfler pendimethalinin farklı konsantrasyonlarına bağlı olarak saatler arasındaki önemli farklılıkları Duncan testine göre $(p<0.05)$ göstermektedir.

Figure 4. Effects of pendimethalin herbicide on total phenolic contents in Dinçer and Remzibey varieties. Different small letters experience changes due to different concentrations of pendimethalin according to Duncan test $(p<0.05)$. 


\section{Lipid peroksidasyonu}

Dinçer çeşidinde en yüksek MDA içeriği 24., 48. ve 72. saatlerde $0.01 \mathrm{M}$ uygulanan gruplarda sırasıyla $13.79 \mu \mathrm{mol}$ MDA g ${ }^{-1} \mathrm{FW}, 14.78 \mu \mathrm{mol}$ MDA g ${ }^{-1} \mathrm{FW}$ ve $16.40 \mu \mathrm{mol} \mathrm{MDA} \mathrm{g}^{-1} \mathrm{FW}$ olarak saptandı. En düşük MDA içeriği ise 24., 48. ve 72. saatlerde kontrol gruplarında belirlendi. Artan konsantrasyonlara bağlı olarak tüm saatlerde MDA içeriğini artış gösterdiği gözlendi. Konsantrasyon artışı ve saatlere bağlı olarak gözlenen bu değişimler istatistiksel olarak anlamlı bulundu (Şekil 5). Remzibey çeşidinde en yüksek MDA içeriği 24., 48. ve 72. saatlerde $0.01 \mathrm{M}$ uygulanan gruplarda sırasıyla $14.88 \mu \mathrm{mol} \mathrm{MDA} \mathrm{g}^{-1}$ FW, $17.44 \mu \mathrm{mol}$ MDA g ${ }^{-1}$ FW ve $18.55 \mu \mathrm{mol}$ MDA $\mathrm{g}^{-1} \mathrm{FW}$ olarak saptandı. En düşük MDA içeriği ise 24., 48. ve 72. saatlerde kontrol gruplarında bulundu. Artan konsantrasyonlara bağlı olarak tüm saatlerde MDA içeriğini artış gösterdiği saptandı. Konsantrasyon artışı ve saatlere bağlı olarak gözlenen bu değişimler istatistiksel olarak anlamlı bulundu (Şekil 5).

ROT, lipidlerle, proteinlerle ve pigmentlerle reaksiyona girerek lipid peroksidasyonuna ve membran hasarına neden olur (Gill ve Tuteja, 2010). Lipid peroksidasyonunun ürünü olan malondialdehid bu nedenle oksidatif stresin göstergesidir (Türkan ve ark., 2005; Langaro ve ark., 2017).

Nohatto ve ark. (2016) tarafından yapılan bir çalışmada, pirinç bitkisine bentazon, penoxsulam ve cyhalofop-butyl herbisitlerinin uygulama sonrasında lipid peroksidasyonunu arttırdığı belirtilmiştir.

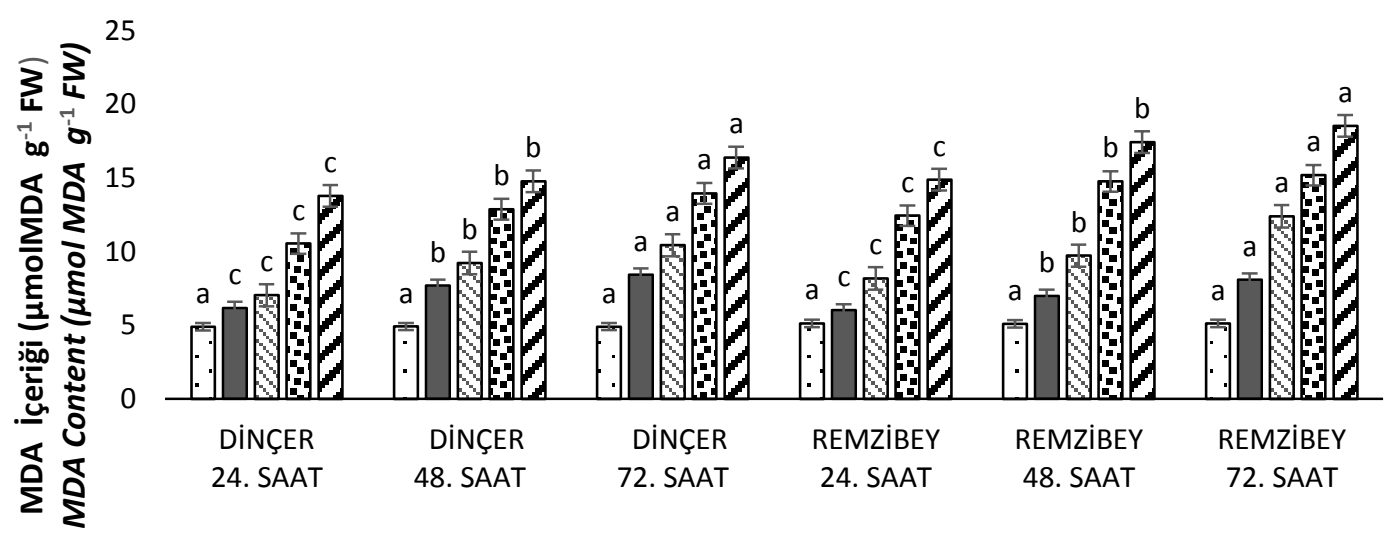

\section{Pendimethalin Konsantrasyonları (M) \\ Pendimethalin Concentrations (M) \\ $\square 0$ (Kontrol) $\square 0.004 \mathrm{M} \quad \square 0.005 \mathrm{M} \quad \square 0.007 \mathrm{M} \quad 0.01 \mathrm{M}$}

Şekil 5. Pendimethalin herbisitinin Dinçer ve Remzibey çeşitlerinde MDA içerikleri üzerine etkileri. Farklı küçük harfler pendimethalinin farklı konsantrasyonlarına bağlı olarak saatler arasındaki önemli farklılıkları Duncan testine göre $(p<0.05)$ göstermektedir.

Figure 5. Effects of pendimethalin herbicide on MDA contents in Dinçer and Remzibey varieties. Different small letters experience changes due to different concentrations of pendimethalin according to Duncan test $(p<0.05)$.

\section{Sonuç}

Önemli bir kültür bitkisi olan aspir (Carthamus tinctorius L.)'in Dinçer ve Remzibey çeşitlerine uygulanan pendimethalin herbisiti strese neden olmuştur. Dinçer ve Remzibey çeşitlerinde karotenoid içeriği kontrole kıyasla azalış gösterirken toplam klorofil içeriği Remzibey çeşitinde Dinçer çeşidine göre daha yüksek saptanmıştır. Toplam karbohidrat içeriği ise Dinçer çeşidinde Remzibey çeşidine kıyasla daha yüksek belirlenmiştir. Toplam fenolik içeriği
Remzibey ve Dinçer çeşitlerinde artan saatlere bağı olarak azalış göstermiştir. Oksidatif hasarın önemli bir belirteci olan MDA içeriği ise Remzibey çeşidinde Dinçer çeşidine göre daha yüksek saptanmıştır. Bu çalışma, aspir bitkisinde pendimethalin uygulamasının toksik etkiye neden olduğunu göstermektedir.

\section{Kaynaklar}

Boukehili, K., Khaldi, F., \& Kharrachi, M. (2015). Impact of two herbicides (Zoom and Sencorate) on physiological parameters (chlorophyll, proline and 
total protein), enzymatic (CAT and APX) and nonenzymatic biomarkers (MDA and GSH) of the species Orthotrichum affine International Journal of Plant \& Soil Science 4 (4): 352-365.

Breusegem, F.V., \& Dat, J.F., (2006). Reactive oxygen species in plant cell death. Plant Physiol. Jun. 141 (2): 384-390.

Büyük, ì., Soydam-Aydın, S., \& Aras, S. (2012). Bitkilerin stres koşullarına verdiği moleküler cevaplar. Türk Hij Den Biyol Derg. 69 (2): 97-110.

Chandler, S.F., \& Dodds, J.H. (1983). The effect of phosphate, nitrogen and sucrose on the production of phenolics and solasidine in callus cultures of Solanum lacinitum, Plant Cell Reports. 2: 105-108.

Dajue, L., \& Mündel, H.H. (1996). Safflower. Carthamus tinctorius L. promoting the conservation and use of underutilized and neglected crops. 7th Edition, Institute of Plant Genetics and Crop Plant Research, Gatersleben/International Plant Genetic, Rome.

De-Kok, L., \& Graham, M. (1980). Levels of pigments, soluble proteins, amino acids and sulfhydryl compounds in foliar tissue of Arabidopsis thaliana during dark induced and natural senescence. Plant Physiology and Biochemistry. 27: 133-142.

Delen, N., Durmuşoğlu, E., Güncan, A., Turgut, C., Güngör, N., \& Burçak, A. (2005). Türkiye'de pestisit kullanımı ve organizmalarda duyarlılık azalışı sorunları, Türkiye Ziraat Mühendisliği 6. Teknik Kongre, 1-21.

Dragičević V., Simić M., Stefanović L., \& Sredojević S. (2010). Possible toxicity and tolerance patterns towards post-emergence herbicides in maize inbred lines. Fresenius Environmental Bulletin. 19: 1499-1504.

Duncan, D.B. (1955). Multiple range and multiple $F$ tests biometrics. Int. Biom. Soc. 11(1): 1-42.

Erdoğan, B.Y. (2010). Samsun'da Yaygın Olarak Kullanılan Pestisitlerin Sağlığa ve Çevreye Etkileri, Alınteri 19 (B) -28-35 ISSN:1307-3311.

Ghanizadeh, H., Harrington, K.C., James, T.K., Woolley, D.J., \& Ellison, N.W. (2015). Mechanisms of glyphosate resistance in two perennial ryegrass (Lolium perenne) populations. Pest Manag Sci. 71(12): 1617-22.

Gilbert, J. (2008). International safflower production - An Overview. 7. International Safflower Conference. Australian Oilseeds Federation. Wagga Wagga, Australia.

Gill, S.S., \& Tuteja, N. (2010). Reactive oxygen species and antioxidant machinery in abiotic stress tolerance in crop plants. Plant Physiol. Biochem. 48: 909-930.

Heap, I. (2014). Global perspective of herbicide-resistant weeds. Pest Management Science 70: 1306-1315.

Heath, R.L., \& Packer, L. (1968). Photoperoxidation in isolated chloroplast, I. kinetics stoichiometry of fatty acid peroxidation. Archives of Biochemistry and Biophysics, 125: 180.

Hoagland, D.R., \& Arnon, D.I. (1938). The water culture method for growing plants without soil, Circ. Calif. Agr. Exp. Sta., 347: 461.

Jha, P., Kumar, V., \& Lim, A. Charlemagne, Yadav R.,( 2017). Evaluation of preemergence herbicides for crop safety and weed control in Safflower. American Journal of Plant Sciences, 8, 2358-2366.

Kışlalıoğlu, M., \& Berkes, F. (1985). Ekoloji ve Çevre
Bilimleri: Türkiye Çevre Sorunları Vakfı Yayını, Ankara, 361.

Langaro, A.C., Agostinetto, D., Ruchel Q., Garcia, J. R., \& Perboni L.T. (2017). Oxidative stress caused by the use of preemergent herbicides in rice crops. Revista Ciência Agronômica. 48 (2) 358-364.

Levitt, J. (1972). Responses of plants to environmental Stresses. New York, London: Academic Press, 697.

Li, G., Wan, S., Zhou, J., Yang, Z., \& Qin, P. (2010). Leaf chlorophyll fluorescence, hyperspectral reflectance, pigments content, malondialdehyde and proline accumulation responses of castor bean (Ricinus communis L.) seedlings to salt stress levels. Industrial Crops and Products. 31: 13-19.

Lichtenthaler, K., \& Welburn, A.R., 1983. Determination of total carotenoids and chlorophylls $a$ and $b$ of leaf extracts in different solvents. Botanisches Institutder Univeristat, Kaiserstran $\beta$ e 12, Postfach. 591-592.

Macedo, R.S., Lombardi A.T., Omachi, C.Y., \& Rorig, L.R. (2008). Effects of the herbicide bentazon on growth and photosystem II maximum quantum yield of the marine diatom Skeletonema costatum, Toxicology in Vitro. 22: 716-722.

Malencic, D.R., Miladinović, J.A., \& Popović, M.T. (2008). Effects of linuron and dimethenamid on antioxidant systems in weeds associated with soybean. Central European Journal of Biology 3(2), 155-160.

Marchezan, M.G., Avila, L.A., Agostinetto, D., Schaedler, C.E., Langaro A.C., Oliveira C., Zimmer, M., \& Schreiber, F. (2017). Morphological and biochemical alterations of paddy rice in response to stress caused by herbicides and total plant submersion. Planta Daninha. 1-13.

Mengistu, L.W., Mueller-Warrant, G.W., Liston, A., \& Barker, R.E., (2000). psb mutation (valine219 to isoleucine) in Poa annua resistant to metribuzin and diuron, Pest Manag. Sci. 56: 209-217.

Nohatto, M.A., Dirceu, A., Langaro, A. C., Oliveira, Claudia de, \& Ruchel, Q., (2016). Antioxidant activity of rice plants sprayed with herbicides. e-ISSN 1983-4063 www.agro.ufg.br/pat - Pesq. Agropec. Trop., Goiânia, 46: 1, 28-34.

Romani, A., Vignolini, P., Galardi, C., Aroldi, C., Vazzana, C., \& Heimler D., (2003). Polyphenolic content in different plant parts of soy cultivars grown under natural conditions. J. Agric. Food Chem. 51: 53015306.

Rosenberg, S. (1980). Physiological studies of lignocellulose degratation by thermotolerant mold Chrysosporium prunosum, Symposium on the biological transformation of lignocellulose, 12: 133-142.

Saladin, G, Magnea, C., \& Cleament, C. (2003). Effects of flumioxazin herbicide on carbon nutrition of Vitis vinifera L., J. Agric. Food Chem., 51: 4017-4022.

Slinkard, K., \& Singleton V.L. (1977). Total phenol analyses: automation and comparison with manual methods, American Journal of Enology and Viticulture. 28: 4955.

Smirnoff, N. (1993). The role of active oxygen in the response of plants to water deficit and desiccation. New Phytol. 125: 27-58.

Squibb, K. (2002). Pesticides, Program in Toxicology NURS 678-Applied Toxicology, 1-48. 
Türkan, i., Bor, M., Özdemir, F., \& Koca, H. (2005). Differential responses of lipid peroxidation and antioxidants in the leaves of drought-tolerant $P$. acutifolius Gray and drought-sensitive $P$. vulgaris L. subjected to polyethylene glycol mediated water stress, Plant Science 168, 223-231.

Van Breusegem, F., \& Dat, J.F. (2006). Reactive oxygen species in plant cell death. Plant Physiol, 141, 384-
90.

Van Camp, W., Van Montagu, M., \& Inze, D. (1998). $\mathrm{H}_{2} \mathrm{O}_{2}$ and NO: Redox signals in disease resistance. Trends Plant Sci, 3: 330-4.

Zhou, Q., Liu W., Zhang Y., \& Liu K.K. (2007). Action mechanisms of acetolactate synthase-inhibiting herbicides, Pesticide Biochemistry and Physiology, 89, 89-96. 